\title{
Quantitative assessment of people-oriented forestry in Bangladesh: A case study in the Tangail Forest Division
}

Nur Muhammed ${ }^{1}$, Masao Koike ${ }^{1 *}$, Farhana Haque ${ }^{1}$ and Md. Danesh Miah ${ }^{2}$

\begin{abstract}
Forests represent more than just a livelihood to many people in developing countries. In Bangladesh, for example, overwhelming poverty and socio-economic pressures have resulted in an unstable situation where intensive pressure on forest resources is having increasingly negative consequences for the population. Some studies have evaluated the benefits of people-oriented forestry activities from an investment, as well as a participant, point of view. In the study area located in the Tangail Forest Division, a total of 11,854 ha of woodlot, 2,704 ha of agroforestry and $945 \mathrm{~km}$ of strip plantations have been raised in a benefit-sharing program that is inclusive of land encroachers and other economically disadvantaged people. Since 2000-2001, a total of 3,716 ha of woodlot, 890 ha of agroforestry and 163 $\mathrm{km}$ of strip plantations have been harvested to the benefit of 6,326 individuals. Investment analysis indicates that woodlot plantation is not financially viable but agroforestry is the most profitable. These results were somewhat unexpected since initial analysis suggested that the woodlot plantation profit would be greater than, or at least equal to, that of the agroforestry plantation if the number of planted seedlings per unit area was taken into account. The per unit area Net Present Value (NPV) was highest in the agroforestry plantation $(\$ 1,662)$ and negative in the woodlot plantation (-\$397). The Benefit Cost Ratio (BCR) was also highest in the agroforestry plantation (1.64) and lowest in the woodlot plantation (0.86). This study also showed that some individuals who were formally classified as encroachers have now become
\end{abstract}

1 Forest Policy Laboratory, Shinshu University, 8304 Minamimminowa, 399-4598 Nagano -ken, Japan. 2 Department of Forest Resources, Kookmin University, Seoul, South Korea. 
* Corresponding author: Email. makoike@gipmc.shinshu-u.ac.jp, Tel. and Fax +81-0265-77-1526.

vital stakeholders. On average, participants received \$800, \$1,866 and \$1,327 over the course of thirteen years from strip, agroforestry and woodlot plantations respectively. Average annual return per participant was \$62, \$144 and \$102 respectively, which was in addition to each individual's yearly income. This added income is a significant contribution to monetary resources and improves socio-economic conditions at a grass roots level. Overall then this program can be considered a financial success as a plantation raising strategy. However, despite this financial progress, the program cannot be considered a true form of participatory people-oriented forestry because it shows serious deviations from the original concept or model for participatory people-oriented forestry that is outlined in the project document. These discrepancies are especially notable with regard to i) beneficiary selection, ii) gender equity, iii) professional attitude and corruption, iv) funding and v) program approach. However, other countries faced with similar challenges of forest overuse and degradation may adopt this practice for achieving self reliance and environmental stability.

Keywords: Bangladesh, People oriented forestry, Sal forests, investment analysis

\section{Introduction}

\subsection{Bangladesh forestry at a glance}

The forested area of Bangladesh is approximately 2.53 million hectares (mill ha), which is about $17.5 \%$ of the country. Major forest types within Bangladesh include i) tropical evergreen and semi-evergreen hill forests, ii) tropical littoral and mangrove forests, iii) inland moist deciduous Sal forests and iv) freshwater swamp forests. Out of the total forested land, the Forest Department (FD) directly controls 1.53 mill ha. The high degree of dependency that many people have on the forests for their livelihood has resulted in depletion of natural resources and degradation of forest ecosystems. Relatively low total land area and a high population (147 mill or 1,127 people $\mathrm{km}^{-2}$ ) have also contributed to the increasingly severe deforestation 
(rate of $0.9 \%$ during the 1970 s and $2.7 \%$ in the $1984-1990$ period). At a population growth rate of $2 \%$ year $^{-1}$ (FAO, 2005), such deforestation is likely to continue if left unchecked (Government of Bangladesh, 2001). Encroachment onto forest land (22\% of hill forests, $38 \%$ of deciduous forests) is responsible for much of the observed loss. Khan et al. (2004) found that a significant portion of the country's designated forestland is in fact devoid of trees. The Forestry Sector Master Plan (FSMP) found a meager 0.84 mill ha, or $5.8 \%$ of the country's landmass, as 'area under forest vegetation’ (Government of Bangladesh, 1995).

\subsection{A brief review of people - oriented forestry activities in Bangladesh}

People-oriented forestry, an alternative to the traditional forestry management approach, has been introduced in Bangladesh in order to increase forest coverage. The goal of people-oriented forestry is to educate, engage and encourage active participation in the management of forest resources, thus creating relevant stakeholders. The Forest Policy of 1979 clearly outlined a participatory approach for all government-owned, degraded forest land as well as plantations on marginal land (Government of Bangladesh, 1979). In 1982, in response to this forest policy, the Asian Development Bank (ADB) supported the first community forestry project of this type. It was located in an environmentally-degraded zone in the northern part of the country. The project was a success, introducing participatory forestry to marginal fallow land such as roadsides, the peripheries of railway lines and institutional premises. People-oriented forestry is also being practiced in degraded forest areas. Interest in the program increased when participants received their share of the benefits generated by the project. This particular project is considered the cornerstone of people-oriented forestry in Bangladesh. Similar people-oriented forestry programs have since been initiated in Bangladesh under various development initiatives. 
Muhammed et al. (2005a) reported that during 2000-2003, more than 23,000 individuals benefited from the final felling of different participatory forestry plantations in Bangladesh. This work has generated a total of US\$ 5.6 mill in government income and US\$ 5.3 mill in participants’ income (US\$ 223 person $^{-1}$ ), plus US\$ 1.2 mill for the Tree Farming Fund (TFF), a 10\% depository reserve set up to support the continuation of these practices in the long-term. Although average individual final returns are not high (US\$ 223 person $^{-1}$ ), some individuals received about US\$ 5,000 to US\$ 8,500 from final felling. That amount was sufficient to significantly improve their standard of living and social position. In a case study on Sal forests at Gazipur district of Dhaka Forest Division in Bangladesh, Muhammed and Koike (2005) found that, on average, every participant received about US\$ 3,688 from the participatory forestry plantation. This included US\$ 653 as an interim benefit and US\$ 3,035 from final harvesting. The individual total benefit therefore ranged from US\$1,968 to US\$ 6,137. Despite the importance of these achievements, no research has been conducted to evaluate the financial efficiency of people-oriented forestry as an investment option.

\subsection{Tangail Forest Division (Study area) and its people-oriented forestry program}

Moist deciduous Sal forests cover an area of about 0.12 mill ha, which is distributed over the relatively drier central and northwestern parts of the country. This includes the districts of Dhaka, Mymensingh, Tangail, Dinajpur, Rangpur, Rajshahi and Comilla (Ismail and Mia, 1973). The dominant species (about $80-100 \%$ ) of these forests is the commercially profitable Sal tree (Shorea robusta) (Ismail, 1968). About 49,748 ha (42\%) of the moist deciduous forests is situated in the Tangail Forest Division, which is comprised of one civil district, including eleven Thanas. Tangail covers 341,400 ha and supports a population of 3.3 mill, with an average literacy rate of 29.4\% (Government of Bangladesh, 2002). Out of the total population of Tangail, about 40,000 Garo (a tribal group) live in 
Madhupur which is one of the Forest Ranges of this Forest Division (Government of Bangladesh., 2001). Encroachment into Sal forests area and removal of trees is severe in this area and forest ecology has been significantly degraded (Muhammed et al., 2000). Because the Tangail Forest Division is located near Dhaka, the capital of Bangladesh, it is subject to the pressures of the higher local population density and subsequent demands for timber and forest land. Illegal encroachment into the forest in this area is very high, with an estimated 31. 9\% of the forest having already been altered for settlement or other purposes (Muhammed et al., 2005a). Areas of altered land use, particularly for agriculture, form a checkerboard, or honeycomb pattern of distribution within the forests. This results in multiple points of interconnected encroachment, which exacerbates the overall problem. (Muhammed et al., 2005b).

Prior to nationalization these forests used to belong to feudal lords employed by the then British-run government (Government of Bangladesh, 1993). Due to various problems the acquisition process took a long time and by that time individuals had managed to produce false property documents. This multiple ownership created issues of land tenure conflict between individuals and the government. This is another important reason for reduced forest cover and land. Moreover, politically influential elite groups occupy the forest land illegally employing dummy encroachers who are essentially poor and land-less. Thus Sal forest areas can be seen to be suffering problems at various levels. Systemized corruption with two-way links between many interested groups including forestry professionals is also responsible for rampant deforestation in Bangladesh. Due to various institutional and management deficiencies the Forest Department itself is inefficient in its role as the state authority for implementing forestry activities.

In order to reduce pressure and improve the general understanding of forest resources, participatory people-oriented forestry activities have been carried out in Tangail forest areas since 1987. During the 1987- 2004 period, 11,854 ha of 
woodlot plantations, 2,704 ha of agroforestry plantations and $945 \mathrm{~km}$ of strip plantations were raised under different participatory forestry programs that actively involved individuals who were previously associated with illegal encroachment. One of the project goals is to actively involve these land encroachers and other local inhabitants as stakeholders through an agreed benefit-sharing mechanism (Tangail Forest Division, 2004). Harvesting of mature trees in the participatory forestry plantation began in the 2000-2001 season. By the 2003-2004 season, 3,716 ha, 890 ha and $163 \mathrm{~km}$ had been harvested from the woodlot, agroforestry, and strip plantation areas respectively. Benefits were distributed among 6326 individuals (Tangail Forest Division, 2004).

Under a people-oriented forestry program, three types of plantations were developed in the study area (Tangail Forest Division): i) strip plantation, ii) agroforestry plantation and iii) woodlot plantation. These plantations represent areas specifically managed for economic benefit through eventual harvesting of trees. A strip plantation is a short rotation plantation established on both sides of various roads and railway lines. Participants are involved in the program through a benefit-sharing mechanism. They include the Forest Department (10\%), local citizens (55\%), Tree Faring Fund (TFF) (10\%), the Land owning agency (20\%) and the Local union council (5\%). Agroforestry represents a kind of land use pattern whereby perennial trees are grown alongside agricultural crops on degraded and denuded government forest land. Participants in agroforestry include the Forest Department (45\%), local citizens (45\%) and TFF (10\%). A woodlot plantation is a block plantation developed on degraded and denuded government forest land. A woodlot plantation involves local people in a benefit sharing system comparable to agroforestry.

\subsection{Conceptual framework for quantitative analysis of forestry investment}

Forestry includes several objectives and potential uses of the natural resources, 
including forest restoration, conservation of diversified species, recreation and business. In order to be successful, a manager must base business decisions on sound financial analysis through an evaluation of alternatives. The basic tools of financial analysis are not new, but their application in forestry investment analysis requires special knowledge. For example, forest managers or tree growers need to critically evaluate tree species that are most likely to have optimal growth rates, when to harvest trees, and when to replant. A key economic difference between forestry land use planning and most agricultural land use planning is that the financial returns from forests may not be forthcoming for several years. Therefore, economic planning must take into consideration the likely degree of change in the value of currency due to inflation or deflation (Friday et al., 2000). Financial analysis generates information crucial to the decision-making process; this information is needed to analyze an investment's profit-making potential, and thus is important in developing financial strategies. When a financial investment is made, the investor expects to eventually receive a positive return in physical or monetary terms (or both) (Elwood et al., 1983). Valuation of an asset, an important factor in making an investment decision, could be determined through either asking price or bid price (Klemperer, 1996). The following criteria are frequently used for selecting viable investment options.

(i) The net present value of the project is greater than zero.

(ii) The discounted value of benefits is at least equal to the value of each project component.

(iii)Project objectives cannot be achieved through other lower-cost alternatives. Obtaining accurate information on growth rates, prices and costs in any particular situation is important to the investment decision-making process since results are only as good as the data used. Although financial gain is not always the only anticipated reward of a project, it is an important driving factor and must be considered when evaluating the viability and likelihood of success of an investment. 
In every investment analysis, whether financial or economic, the following steps are taken (Elwood et al., 1983).

(i) determine the desired objective

(ii) organise the procedure

(iii) gather necessary data / information (physical and financial)

(iv) calculation / analysis

(v) study the results and re-examine the initial assumptions

Once the appropriate conceptual and temporal analytical boundaries have been set for a project analysis, an evaluation method is selected (Dixon et al., 1986). Net Present Value (NPV), Internal Rate of Return (IRR) and Benefit Cost Ratio (BCR) techniques are frequently used to assess monetary profitability. These three evaluation methods rely on the same information; specifically, the yearly generation of benefits, and costs associated with the project over the appropriate time period (Gittinger, 1982; Mishan, 1982). But although these three procedures may use the same information, they produce different results. As this study was an investigation on the completed project, IRR was not considered appropriate.

\section{Materials and methods}

This research, based on case study analysis, was conducted to evaluate the profitability of three different types of plantation raised through a people-oriented forestry program in Tangail Forest Division in Bangladesh. The three types of plantation were strip, agroforestry and woodlot. The study was divided into different phases of review and data acquisition. In the preparatory phase, a search was conducted for major relevant documents, which were obtained and reviewed. In the data collection phase, field visits were made to the Banstoil and Dholapara Ranges of the Tangail Forest Division. Fifty-two respondents were randomly selected from the two forest ranges (17 participants from the strip plantation, 17 from the agroforestry plantation and 18 from the woodlot plantation). Among the 
52 respondents surveyed only two were found to be female beneficiaries (3.8\%). Although the ratio between male-female participants is supposed to be $1: 1$, in practice this is rarely the case. Moreover, it was found that there were no female participants in strip plantation and woodlot plantation among the surveyed respondents. This gender bias is widespread not only in the study areas but also across all areas of social forestry in Bangladesh.

A semi-structured questionnaire was used. Interaction with interviewees was generally informal, and included two-way communication. This method helped accommodate the wide diversity of opinions, knowledge and experience of the interviewees. The goal of the interviews was to determine participants' demographic and socio-economic status as well as the maintenance costs of and financial gains from the plantation plots.

Annual plantation raising and management costs were obtained from the Tangail Divisional Forest office. As there was no record of plantation-specific staff salary and administrative costs, yearly costs for the whole forest range were divided by the total area of the range to arrive at a per hectare cost and plantation-specific costs were then derived from this. Land tax was calculated from the official rate fixed by the land administration authority of the country. In an investment analysis of a teak plantation in Bangladesh, Muhammed et al. (2004) adopted similar techniques for calculating staff salary and administrative costs. The prevailing bank rate of interest (8\% in this case) was used to calculate the rate of inflation over the period of plantation growth.

In addition to the individual interviews, Focus Group Discussion (FGD) - a useful PRA (Participatory Resource Assessment) technique - was also used to promote closer interaction with the interviewees in the hope of obtaining more uninhibited and realistic responses. Information gathered from the field was collated, processed and analysed with non-parametric statistical methods using SPSS and Microsoft Excel. The following formulas were used to calculate the Net 
Present Value and Benefit Cost Ratio:

$$
N P V=\sum_{t=0}^{n} \frac{B_{t}-C_{t}}{(1+r)^{t}} \quad B C R=\frac{\sum_{t=0}^{n} B_{t} /(1+r)^{n}}{\sum_{t=0}^{n} C_{t} /(1+r)^{n}}
$$

$\mathrm{NPV}=$ Net Present Value, BCR $=$ Benefit Cost Ratio, Bt $=$ Benefits, $\mathrm{Ct}=$ Costs, $\mathrm{r}=$ discount rate, $\mathrm{t}=$ time (from 0 to $\mathrm{n}$ years)

\section{Results}

\subsection{Demography, land use and income of the participants}

Under the policy and program structure, poor farming families are targeted for inclusion in people-oriented participatory forestry programs in Bangladesh. They own and farm very little land, are poorly educated and represent the bottom end of society among the rural poor. By these criteria, most of the participants would in theory maintain only a marginal livelihood. But in practice there was a bias in participant selection. In most cases, genuinely poor people could not become participants at first because the forest land was illegally occupied by the rich and local elites who created problems when they were not selected as participants. However, from the $2^{\text {nd }}$ rotation there was a change in participant selection. After observing and experiencing the financial benefits, the genuinely poor were much more motivated and better committed to the program. Therefore, from the $2^{\text {nd }}$ rotation on, actual land-less and poor people had more scope for becoming participants. But the response of the foresters has not been especially welcoming. Priority has repeatedly been given to the local elite and politically dominant groups for personal benefit.

It was found that the average size of the respondent's family is five (with a range of 2 to 10) and the average number of children per family is four (ranging from 1 to 8 ) (Table 1). The average amount of land held by a family is approximately 0.18 ha (0.004 to $0.81 \mathrm{ha})$. Land is utilized primarily for farming, 
housing and minimal forestry applications. On the average, each family includes two wage earners and average annual family income and expenditures were US\$ 728 (US\$ 332 to US\$ 4,526) and US\$ 589 (US\$ 272 to US\$ 1,509), respectively.

Table 1: Demography, land use and income level of the participants*

\begin{tabular}{|c|c|c|c|c|c|c|}
\hline Parameters & Total & Mean & Minimum & Maximum & $\begin{array}{l}\text { Std. } \\
\text { Deviation }\end{array}$ & $\begin{array}{l}\text { Std. } \\
\text { Error }\end{array}$ \\
\hline \multicolumn{7}{|l|}{ a. Household size } \\
\hline Family member & 272 & 5 & 2 & 10 & 1.8 & 0.25 \\
\hline Number of children & 196 & 4 & 1 & 8 & 1.9 & 0.26 \\
\hline \multicolumn{7}{|c|}{ b. Land holdings and landuse pattern } \\
\hline Land holdings (ha) & 9.35 & 0.18 & 0.004 & 0.81 & 0.40 & 0.06 \\
\hline Housing (ha) & 3.48 & 0.07 & 0.004 & 0.02 & 0.12 & .02 \\
\hline Farming (ha) & 5.77 & 0.11 & 0 & 0.65 & 0.34 & .05 \\
\hline Forestry (ha) & 0.08 & 0 & 0 & 0.08 & 0.03 & 0 \\
\hline \multicolumn{7}{|c|}{ c. Annual income and expenditure } \\
\hline Earning member (no) & 95 & 2 & 1 & 4 & 0.79 & 0.11 \\
\hline Annual income (US\$) & 37870 & 728 & 332 & 4526 & 666 & 92 \\
\hline Primary source (US\$) & 25106 & 483 & 181 & 3168 & 499 & 69 \\
\hline Secondary source (US\$) & 11632 & 224 & 0 & 1056 & 171 & 24 \\
\hline Other sources (US\$) & 920 & 18 & 0 & 226 & 51 & 7 \\
\hline $\begin{array}{l}\text { Total annual expenditure } \\
\text { (US\$) }\end{array}$ & 30628 & 589 & 272 & 1509 & 213 & 30 \\
\hline
\end{tabular}

Source: Field survey, 2004.

*Total number of respondents $=52$ (male-50 and female 2).

\subsection{Respondents as participants of people-oriented forestry}

The respondents that were interviewed joined the people-oriented forestry program in 1992 (Table 2). Each respondent in each of the three plantation categories was allocated land as follows; 300 meters (both sides of the strip in strip plantation), 1 ha (in agroforestry) and 1.21 ha (in woodlot plantation). The number of seedlings planted per individual plot in each of the strip, agroforestry and woodlot plantations was 300, 1,600 and 3,636 respectively. The average number of trees felled per plot was 139, 650 and 1,033 respectively. Although the planned rotation period for these three types of plantation was 10 years, the actual tree felling occurred after 13 years (i.e. there was a delay of 3 years). And from the 
interviews it emerged that not only was there a delay in plantation felling, but also a delay of six to eight months in the distribution of benefit shares to the participants after felling by the implementing agency (Forest Department).

The information on the financial benefit to the participants and government has been collected from the official plantation and felling register of the respective two Forest Ranges. Cross checking was done while making the Focus Group Discussion (FGD). In fact the mature social forestry plantation was felled by the participants and forest staff, while timber produce (such as timber and firewood) was sold through open auction by the forest official in the presence of participants. Therefore, the participants had no direct claim to the plantation felling and sale. The financial return was presented to the participants via a Bank Check distribution ceremony chaired by the local Minister/ Member of the Parliament (MP) to make the process transparent and acceptable to all stakeholders.

Table 2: Summary of respondent's forestry activities

\begin{tabular}{llll}
\hline \multirow{2}{*}{ Parameters } & \multicolumn{3}{c}{ Plantation category } \\
\cline { 2 - 4 } & Strip & Agroforestry & Woodlot \\
\hline Area (km/ha) & 0.3 & 1 & 1.21 \\
Year of planting & 1992 & 1992 & 1992 \\
Year of felling & 2004 & 2004 & 2004 \\
Rotation (years) & 10 & 10 & 10 \\
Required period (years) & 13 & 13 & 13 \\
Delay in felling (years) & 3 & 3 & 3 \\
Delay in payment (months) & 6 & 7 & 8 \\
Seedlings planted per unit & 300 & 1,750 & 3,636 \\
Average no. of trees felled & 139 & 650 & 1033 \\
\hline
\end{tabular}

Source: Field survey, 2004.

\subsection{Quantitative analysis of the people-oriented forestry program}

\subsubsection{Strip plantation}

Financial information of 17 respondents in the strip plantation category was 
used for this analysis, thus representing an area of $5.1 \mathrm{~km}\left(300 \mathrm{~m}\right.$. respondent $\left.{ }^{-1}\right)$. It was found that Net Present Value and Benefit-Cost Ratio calculations of the strip plantation were US\$ 8,325 and 1.47, respectively. The strip plantation was therefore not only profitable for the participants (particularly since they had no cost commitment except the physical labor needed to protect the plantation) but also from the point of view of the government investment.

Table 3: Financial analysis of the strip plantation

\begin{tabular}{|c|c|c|c|c|c|c|c|}
\hline Year & Activities & $\begin{array}{l}\text { Total } \\
\text { cost } \\
\text { (US\$) }\end{array}$ & $\begin{array}{l}\text { Total } \\
\text { benefits } \\
\text { (US\$) }\end{array}$ & $\begin{array}{l}\text { Cashflow } \\
\text { (US\$) }\end{array}$ & $\begin{array}{l}\text { Compounded } \\
\text { cash flow } \\
\text { (US\$) at } 8 \%\end{array}$ & $\begin{array}{l}\text { Compounded } \\
\text { cost (US\$) } \\
\text { at } 8 \%\end{array}$ & $\begin{array}{l}\text { Compounded } \\
\text { benefits } \\
\text { (US\$) at 8\% }\end{array}$ \\
\hline 0 & Raising Seedlings & 762 & 0 & -762 & -1918 & 1,918 & 0 \\
\hline 0 & Planting cost & 231 & 0 & -231 & -581 & 581 & 0 \\
\hline 0 & Maintenance cost & 192 & 0 & -192 & -484 & 484 & 0 \\
\hline 0 & Incentive & 0 & 943 & 943 & 2,375 & 0 & 2,375 \\
\hline 0 & Interim production & 15 & 60 & 45 & 114 & 38 & 152 \\
\hline 1 & Vacancy filling & 46 & 0 & -46 & -108 & 108 & 0 \\
\hline 1 & Maintenance cost & 192 & 0 & -192 & -449 & 449 & 0 \\
\hline 1 & Incentive & 0 & 943 & 943 & 2,199 & 0 & 2,199 \\
\hline 1 & Interim production & 30 & 121 & 91 & 211 & 70 & 281 \\
\hline 11 & Tree marking & 231 & 0 & -231 & -249 & 249 & 0 \\
\hline 12 & Final harvesting & 769 & 20,958 & 20,188 & 20,188 & 769 & 20,958 \\
\hline \multicolumn{8}{|c|}{ Compounded costs for $\mathrm{SAAD}^{\mathrm{a}}$ as equal payment to every } \\
\hline year & & & & & $-12,972$ & 12,972 & 0 \\
\hline Sum & & 2,469 & 23,024 & 20,556 & 8,325 & 17,640 & 25,965 \\
\hline NPV & & & & & 8,325 & & \\
\hline BCR & & & & & 1.47 & & \\
\hline
\end{tabular}

Area: 5.1 km, planting year: 1992, felling year: 2004.

Seedling raising: 1000 seedlings/km plus 20\% additional for vacancy filling at US\$ 0.124/seedlings; planting cost: 1000 seedlings/km at US\$ 0.045/seedlings; maintenance cost: @ US\$ 0.038/seedling (first and second year); tree marking: US\$ 45.3/km; harvesting: US\$ 150.9/km; rate of interest: bank money lending rate 8\%.

${ }^{\text {a }}$ SAAD: salary and administrative cost at US\$ 603.5/year.

\subsubsection{Agroforestry plantation}

In the agroforestry plantation, each participant was allocated 1 ha of degraded 
forest land where they utilized the alley cropping model. In this model, alternating space is provided for trees and cereal agricultural crops. The first three meters were for trees and three rows were planted with a spacing of $1.5 \mathrm{~m} \times 1.5 \mathrm{~m}$. The next nine meters were dedicated to agricultural crops. This pattern of trees and agricultural crops was repeated until the agroforestry plot was filled. An estimated 1,600 trees $\mathrm{ha}^{-1}$ was planted in this manner. Financial analysis based on information provided by 17 respondents, and that of the Tangail Forest Division, revealed that this type of

Table 4: Financial analysis of the agroforestry plantation

\begin{tabular}{|c|c|c|c|c|c|c|c|}
\hline Year & Activities & $\begin{array}{l}\text { Total cost } \\
\text { (US\$) }\end{array}$ & $\begin{array}{l}\text { Total } \\
\text { benefits } \\
\text { (US\$) }\end{array}$ & $\begin{array}{l}\text { Cashflow } \\
\text { (US\$) }\end{array}$ & $\begin{array}{l}\text { Compounded } \\
\text { cashflow } \\
\text { (US\$) at 8\% }\end{array}$ & $\begin{array}{l}\text { Compounded } \\
\text { cost (US\$) } \\
\text { at } 8 \%\end{array}$ & $\begin{array}{l}\text { Compounded } \\
\text { benefits } \\
\text { (US\$) at 8\% }\end{array}$ \\
\hline 0 & Raising Seedlings & 4,444 & 0 & $-4,444$ & $-11,190$ & 11,190 & 0 \\
\hline 0 & Planting cost & 1,347 & 0 & $-1,347$ & $-3,391$ & 3,391 & 0 \\
\hline 0 & Maintenance cost & 1,122 & 0 & $-1,122$ & $-2,826$ & 2,826 & 0 \\
\hline 0 & Incentive & 0 & 211 & 211 & 532 & 0 & 532 \\
\hline 0 & Interim production & 679 & 6,035 & 5,356 & 13,487 & 1,710 & 15,197 \\
\hline 1 & Vacancy filling & 269 & 0 & -269 & -628 & 628 & 0 \\
\hline 1 & Maintenance cost & 1,122 & 0 & $-1,122$ & $-2,616$ & 2,616 & 0 \\
\hline 1 & Incentive & 0 & 211 & 211 & 493 & 0 & 493 \\
\hline 1 & Interim production & 785 & 5,869 & 5,084 & 11,855 & 1,829 & 13,684 \\
\hline 2 & Interim production & 830 & 3,772 & 2,942 & 6,352 & 1,792 & 8,143 \\
\hline 3 & Interim production & 830 & 1,886 & 1,056 & 2,111 & 1,659 & 3,770 \\
\hline 4 & Interim production & 377 & 468 & 91 & 168 & 698 & 866 \\
\hline 11 & Tree marking & 256 & 0 & -256 & -277 & 277 & 0 \\
\hline 12 & Final harvesting & 1,795 & 29,504 & 27,709 & 27,709 & 1,795 & 29,504 \\
\hline \multicolumn{2}{|c|}{$\begin{array}{l}\text { Compounded costs for } \\
\text { payment to every year }\end{array}$} & $\mathrm{AAD}^{\mathrm{a}}$ and & Land tax & as equal & $-13,524$ & 13,524 & 0 \\
\hline \multicolumn{2}{|c|}{ Sum } & 13,856 & 47,956 & 34,100 & 28,255 & 43,934 & 72,189 \\
\hline \multicolumn{2}{|l|}{ NPV } & & & & 28,255 & & \\
\hline \multicolumn{2}{|l|}{ BCR } & & & & 1.64 & & \\
\hline
\end{tabular}

Area: 17 ha, plantation year: 1992, felling year: 2004.

Seedling raising: 1750 seedlings/ha plus 20\% additional for vacancy filling at US\$ 0.124/seedlings; planting cost: 1750 seedlings/ha at US\$ 0.045/seedlings; maintenance cost: at US\$ 0.038/seedling (first and second year); tree marking: 
US\$ 15.1/ha, harvesting: US\$ 105.6/ha; land tax: at US\$ 1.5/ha/year; rate of interest: bank money lending rate 8\%.

${ }^{\mathrm{a}}$ SAAD: salary and administrative cost at US\$ 603.5/year.

plantation was also profitable for participants and the government (Table 4). NPV

and BCR of the agroforestry plantation were US\$ 28,255 and 1.64 respectively.

\subsubsection{Woodlot plantation}

Each of the 18 respondents was allocated 1.21 ha of degraded forest for a woodlot plantation, resulting in a total of 21.86 ha. The plantation was initiated in 1992 and trees were harvested in 2004. Financial analysis indicated that the woodlot plantation was not profitable for the government (Table 5). It was, however, profitable for participants since they did not incur any expenses except for off-farm family labor. The NPV and BCR for this type of plantation were US\$ -8,687 and 0.86 .

Table 5: Financial analysis of the woodlot plantation

\begin{tabular}{|c|c|c|c|c|c|c|c|}
\hline Year & Activities & $\begin{array}{l}\text { Total cost } \\
\text { (US\$) }\end{array}$ & $\begin{array}{l}\text { Total } \\
\text { benefits } \\
\text { (US\$) }\end{array}$ & $\begin{array}{l}\text { Cashflow } \\
\text { (US\$) }\end{array}$ & $\begin{array}{l}\text { Compounded } \\
\text { cashflow } \\
\text { (US\$) at 8\% }\end{array}$ & $\begin{array}{l}\text { Compounded } \\
\text { cost (US\$) at } \\
8 \%\end{array}$ & $\begin{array}{l}\text { Compounded } \\
\text { benefits } \\
\text { (US\$) at 8\% }\end{array}$ \\
\hline 0 & Raising Seedlings & 9,776 & 0 & $-9,776$ & $-24,617$ & 24,617 & 0 \\
\hline 0 & Planting cost & 2,962 & 0 & $-2,962$ & $-7,460$ & 7,460 & 0 \\
\hline 0 & Maintenance cost & 2,469 & 0 & $-2,469$ & $-6,216$ & 6,216 & 0 \\
\hline 1 & Vacancy filling & 592 & 0 & -592 & $-1,381$ & 1,381 & 0 \\
\hline 1 & Maintenance cost & 2,469 & 0 & $-2,469$ & $-5,756$ & 5,756 & 0 \\
\hline 11 & Tree marking & 330 & 0 & -330 & -356 & 356 & 0 \\
\hline 12 & Final harvesting & 2,309 & 53,090 & 50,781 & 50,781 & 2,309 & 53,090 \\
\hline \multicolumn{2}{|c|}{$\begin{array}{l}\text { Compounded costs for } \\
\text { payment to every year }\end{array}$} & $\mathrm{SAAD}^{\mathrm{a}}$ and & Land tax & as equal & $-13,681$ & 13,681 & 0 \\
\hline \multicolumn{2}{|c|}{ Sum } & 20,907 & 53,090 & 32,183 & -8687 & 61,777 & 53,090 \\
\hline \multicolumn{2}{|l|}{ NPV } & & & & $-8,687$ & & \\
\hline \multicolumn{2}{|l|}{ BCR } & & & & 0.86 & & \\
\hline
\end{tabular}

Area: 21.86 ha, plantation year: 1992, felling year: 2004 .

Seedling raising: 2980 seedlings/ha plus 20\% additional for vacancy filling at US\$ 0.124/seedlings; planting cost: 2980 seedlings/ha at US\$ 0.045/seedlings; maintenance cost: at US\$ 0.038/seedling (first and second year); tree marking: US\$ 15.1/ha; harvesting: US\$ 105.6/ha; land tax: at US\$ 1.5/ha/year; rate of interest used: bank money lending rate 8\%. 
${ }^{\mathrm{a}}$ SAAD: salary and administrative cost at US\$ 603.5/year.

3.4. Comparative financial efficiency of strip, agroforestry and woodlot plantations

Per unit (km/ha) compounded costs were highest in the strip plantation (US\$ 3,459), followed by the woodlot plantation (US\$ 2,826) and agroforestry plantation (US\$ 2,584) (Table 6). Per unit compounded benefits were also highest in the strip plantation (US\$ 5,091), followed by agroforestry (US\$ 4,246) and woodlot (US\$ 2,429). The highest NPV was calculated for the agroforestry plantation (US\$ 1,662) but in the woodlot plantation the figure was negative (US\$ -397). Similarly, the highest BCR was determined for the agroforestry plantation (1.64) and the lowest was calculated for the woodlot plantation (0.86); the strip plantation was in the middle at 1.47. When the overall investments are taken into consideration, strip and agroforestry plantations can be said to be profitable while woodlot was not. However, from the participants' point of view all three plantation types were profitable since no direct cost commitment was required.

Table 6: Comparative financial return from the three types of plantation

\begin{tabular}{llll}
\hline Financial parameters & $\begin{array}{l}\text { Strip plantation } \\
\text { (per km basis) }\end{array}$ & $\begin{array}{l}\text { Agroforestry plantation } \\
\text { (per ha basis) }\end{array}$ & $\begin{array}{l}\text { Woodlot plantation } \\
\text { (per ha basis) }\end{array}$ \\
\hline Compounded costs (US\$) & 3,459 & 2,584 & 2,826 \\
Compounded benefits (US\$) & 5,091 & 4,246 & 2,429 \\
NPV (US\$) & 1,632 & 1,662 & -397 \\
BCR & 1.47 & 1.64 & 0.86 \\
\hline
\end{tabular}

Source: extracted from Table 3-5.

\subsection{Impact on participant's income level}

Details on financial return from each plantation are shown in Tables 7, 8 and 9. The average base income of the respondents of strip, agroforestry and woodlot 
plantations was US\$ 733, US\$ 936 and US\$ 527 respectively. On average, the participants received US\$ 678, US\$ 781 and US\$1,327 from the final felling of the strip, agroforestry and woodlot plantations respectively. Adding the interim benefits, the average total return per respondent from these three plantations became US\$ 800 , US\$ 1,866 and US\$1,327 respectively; but it took thirteen years for that return to be realized. Given the total time period, the average annual ${ }^{-1}$ return per participant $^{-1}$ from the forestry practices was US\$ 62, US\$ 144 and US\$ 102 respectively. The program therefore provided important income to participants. The influx of significant additional monetary resources may have contributed to an improvement in overall socio-economic condition which, in turn, will have positive repercussions on economic and social freedom (Muhammed and Koike, 2005).

Table 7: Financial return scenario from the strip plantation

\begin{tabular}{|c|c|c|c|c|c|c|}
\hline \multirow[t]{2}{*}{ Respondents ID } & \multirow{2}{*}{$\begin{array}{l}\text { Base } \\
\text { income } \\
\text { (US\$) }\end{array}$} & \multicolumn{4}{|c|}{ Financial return from Strip plantation (US\$) } & \multirow{2}{*}{$\begin{array}{l}\text { Additional yearly } \\
\text { income from } \\
\text { forestry }^{\mathrm{a}}\end{array}$} \\
\hline & & Agri crop & $\begin{array}{l}\text { Other } \\
\text { incentives }\end{array}$ & $\begin{array}{l}\text { Final } \\
\text { felling }\end{array}$ & $\begin{array}{l}\text { Total } \\
\text { return }\end{array}$ & \\
\hline 1 & 422 & 0 & 377 & 558 & 935 & 72 \\
\hline 2 & 573 & 15 & 226 & 619 & 860 & 66 \\
\hline 3 & 709 & 30 & 377 & 754 & 1,162 & 89 \\
\hline 4 & 830 & 0 & 0 & 528 & 528 & 41 \\
\hline 5 & 558 & 30 & 45 & 709 & 785 & 60 \\
\hline 6 & 739 & 15 & 45 & 558 & 619 & 48 \\
\hline 7 & 724 & 0 & 0 & 1,313 & 1,313 & 101 \\
\hline 8 & 1,358 & 0 & 0 & 498 & 498 & 38 \\
\hline 9 & 800 & 15 & 377 & 619 & 1,011 & 78 \\
\hline 10 & 830 & 0 & 0 & 830 & 830 & 64 \\
\hline 11 & 1,056 & 30 & 377 & 905 & 1,313 & 101 \\
\hline 12 & 679 & 0 & 0 & 294 & 294 & 23 \\
\hline 13 & 619 & 15 & 45 & 415 & 475 & 37 \\
\hline 14 & 649 & 0 & 0 & 709 & 709 & 55 \\
\hline 15 & 935 & 0 & 0 & 634 & 634 & 49 \\
\hline 16 & 483 & 30 & 15 & 905 & 951 & 73 \\
\hline 17 & 498 & 0 & 0 & 679 & 679 & 52 \\
\hline Sum & 12,462 & 181 & 1,886 & 11,527 & 13,594 & 1,046 \\
\hline Mean & 733 & 11 & 111 & 678 & 800 & 62 \\
\hline
\end{tabular}

Source: Field survey, 2004.

${ }^{\mathrm{a}}$ The total income from strip plantation took 13 years.

\section{Discussion and Conclusions}


The three types of plantations described herein were all profitable for the participants, resulting in an increase in the annual income of the respondents. Investment analysis indicated that while woodlot plantations were not financially viable, agroforestry and, to a lesser extent, strip plantation farming was profitable. Initial evaluations assumed that the profitability of the woodlot plantation would be greater than, or at least equal to, the agroforestry plantation if the number of planted seedlings per unit area was taken into account. Possible reasons identified for low profitability of the woodlot plantation include species selection, negligence by

Table 8: Financial return scenario from the agroforestry plantation

\begin{tabular}{|c|c|c|c|c|c|c|}
\hline \multirow[t]{2}{*}{$\begin{array}{l}\text { Respondents } \\
\text { ID }\end{array}$} & \multirow[t]{2}{*}{$\begin{array}{l}\text { Base income } \\
\text { (US\$) }\end{array}$} & \multicolumn{4}{|c|}{$\begin{array}{l}\text { Financial return from agroforestry plantation } \\
\text { (US\$) }\end{array}$} & \multirow{2}{*}{$\begin{array}{l}\text { Additional yearly } \\
\text { income from } \\
\text { forestry }^{\mathrm{a}}\end{array}$} \\
\hline & & Agri crop & $\begin{array}{l}\text { Other } \\
\text { incentives }\end{array}$ & $\begin{array}{l}\text { Final } \\
\text { felling }\end{array}$ & $\begin{array}{l}\text { Total } \\
\text { return }\end{array}$ & \\
\hline 1 & 558 & 1,660 & 15 & 1,418 & 3,093 & 238 \\
\hline 2 & 407 & 1,132 & 30 & 1,177 & 2,339 & 180 \\
\hline 3 & 604 & 1,207 & 45 & 1,494 & 2,746 & 211 \\
\hline 4 & 558 & 604 & 15 & 724 & 1,343 & 103 \\
\hline 5 & 513 & 604 & 15 & 468 & 1,086 & 84 \\
\hline 6 & 634 & 1,086 & 60 & 905 & 2,052 & 158 \\
\hline 7 & 362 & 830 & 15 & 649 & 1,494 & 115 \\
\hline 8 & 377 & 1,056 & 30 & 573 & 1,660 & 128 \\
\hline 9 & 679 & 981 & 0 & 1,056 & 2,037 & 157 \\
\hline 10 & 347 & 875 & 30 & 573 & 1,479 & 114 \\
\hline 11 & 981 & 1,207 & 45 & 905 & 2,158 & 166 \\
\hline 12 & 830 & 1,056 & 15 & 438 & 1,509 & 116 \\
\hline 13 & 558 & 1,207 & 0 & 453 & 1,660 & 128 \\
\hline
\end{tabular}




\begin{tabular}{lllllll}
14 & 528 & 1,132 & 30 & 453 & 1,614 & 124 \\
15 & 438 & 1,132 & 15 & 785 & 1,931 & 149 \\
16 & 3,018 & 1,056 & 30 & 392 & 1,479 & 114 \\
17 & 4,526 & 1,207 & 30 & 815 & 2,052 & 158 \\
Sum & 15,917 & 18,030 & 422 & 13,277 & 31,729 & 2,441 \\
Mean & 936 & 1,061 & 25 & 781 & 1,866 & 144 \\
\hline
\end{tabular}

Source: Field survey, 2004.

${ }^{\mathrm{a}}$ The total income from agroforestry plantation took 13 years.

Table 9: Financial return scenario from the woodlot plantation

\begin{tabular}{|c|c|c|c|c|c|c|}
\hline \multirow[b]{2}{*}{$\begin{array}{l}\text { Respondents } \\
\text { ID }\end{array}$} & \multirow[b]{2}{*}{$\begin{array}{l}\text { Base } \\
\text { income } \\
\text { (US\$) }\end{array}$} & \multicolumn{4}{|c|}{ Financial return from woodlot plantation (US\$) } & \multirow{2}{*}{$\begin{array}{l}\text { Additional yearly } \\
\text { income from } \\
\text { forestry }^{\mathrm{a}}\end{array}$} \\
\hline & & Agri crop & $\begin{array}{l}\text { Other } \\
\text { incentives }\end{array}$ & $\begin{array}{l}\text { Final } \\
\text { felling }\end{array}$ & $\begin{array}{l}\text { Total } \\
\text { return }\end{array}$ & \\
\hline 1 & 332 & 0 & 0 & 896 & 896 & 69 \\
\hline 2 & 453 & 0 & 0 & 1,352 & 1,352 & 104 \\
\hline 3 & 362 & 0 & 0 & 1,168 & 1,168 & 90 \\
\hline 4 & 422 & 0 & 0 & 1,154 & 1,154 & 89 \\
\hline 5 & 453 & 0 & 0 & 943 & 943 & 73 \\
\hline 6 & 453 & 0 & 0 & 981 & 981 & 75 \\
\hline 7 & 634 & 0 & 0 & 890 & 890 & 68 \\
\hline 8 & 377 & 0 & 0 & 1,154 & 1,154 & 89 \\
\hline 9 & 981 & 0 & 0 & 1,282 & 1,282 & 99 \\
\hline 10 & 453 & 0 & 0 & 981 & 981 & 75 \\
\hline 11 & 588 & 0 & 0 & 2,263 & 2,263 & 174 \\
\hline 12 & 377 & 0 & 0 & 1,358 & 1,358 & 104 \\
\hline 13 & 362 & 0 & 0 & 1,351 & 1,351 & 104 \\
\hline 14 & 543 & 0 & 0 & 1,011 & 1,011 & 78 \\
\hline 15 & 619 & 0 & 0 & 1,418 & 1,418 & 109 \\
\hline 16 & 724 & 0 & 0 & 1,660 & 1,660 & 128 \\
\hline 17 & 679 & 0 & 0 & 1,856 & 1,856 & 143 \\
\hline 18 & 679 & 0 & 0 & 2,173 & 2,173 & 167 \\
\hline Sum & 9,490 & 0 & 0 & 23,890 & 23,890 & 1838 \\
\hline Mean & 527 & 0 & 0 & 1,327 & 1,327 & 102 \\
\hline
\end{tabular}

Source: Field survey, 2004.

${ }^{\mathrm{a}}$ The total income from woodlot plantation took 13 years.

participants in plantation care and maintenance, and illegal felling due to the delay 
in planned felling. There is a possibility, therefore, that a woodlot plantation could be managed as a profitable enterprise if the above variables were controlled and directed in a positive manner.

Overall then this program can be considered a financial success as a plantation raising strategy. But it seriously fails to follow the original concept or model for participatory people-oriented forestry as outlined in the project document, especially with regards to criteria such as i) beneficiary selection, ii) gender equity, iii) professional attitude and corruption, iv) funding and v) program approach. From the respondents interview it was found that the beneficiary selection criteria has not been followed i.e. true land-less and poor people are not being selected. Instead, the local elites and groups with political support are dominating the beneficiary groups of this program. Moreover, men and women should get equal opportunities (1:1) to become a beneficiary of this program. But female participation in people-oriented forestry is very low; among the respondents interviewed, only 3.8\% respondents were women. Hence gender balance and equality need to be maintained to meet the major ethics of this type of program. Multiple complexities of land tenure including rampant deforestation exist in the study area due to chain corruption. As the implementing agency, the Forest Department in Bangladesh plays a key role in this highly inefficient chain. Meanwhile the attitude of these professionals is not one that seeks active inclusion of genuinely poor people, a fact demonstrated by their lack of proper integration into the program. Achievements of people-oriented forestry such as employment generation, capacity building, institutional development and human and capital formation in the rural areas through benefit sharing arrangements are made under different external aid projects. Without this external assistance, these achievements would be difficult to sustain (Khan, 1998; ADB, 2000; Choudhury, 2001). Therefore, social forestry should be implemented by the government as part of a sustainable forestry policy. 
In conclusion, people-oriented programs like those described here could be a key factor in not only alleviating significant poverty but also in stemming the tide of rampant deforestation. Ultimately, recovery and maintenance of healthy forest ecosystems will provide the greatest benefit for the greatest number of people through production of economically valuable commodities and protection against excessive erosion and flooding. Success in Bangladesh may encourage implementation in other countries that face similar forest degradation.

\section{Acknowledgements}

The authors sincerely acknowledge the support and assistance provided by the Bangladesh Forest Department during data collection. Special thanks to Mr. Iklil Mondal, Project Director, Forestry Sector Project, who provided very essential guidelines and recently published literature in this field. Acknowledgments are due to Mr. Abu Hanif Patwary, Divisional Forest Officer of Tangail and Mr. Kajol Talukdar, Assistant Conservator of Forests of Tangail Forest Division for their all round help during data collection. The authors also acknowledge the Ministry of Science and Education, Japan who granted scholarships supporting the research and study of the first author. Finally, the authors gracefully acknowledge the valuable comments, critics and suggestions made by the anonymous reviewers for overall improvement of the article.

\section{References}

ADB, 2002. Bangladesh Country Case Study Report, Regional Study on Forest Policy and Institutional Reforms, RETA 5900, AWFN, Asian Development Bank, Manila.

Choudhury, J.K., 2001. Does Forestry Pay in Bangladesh? Lessons from ADB's Forest Sector Projects, paper presented in the Forestry Sector Workshop organized by the Forest Department and the ADB, Dhaka. 
Dixon, J.A., Carpenter, R.A., Fallon, L.A., Sherman, P.B., Manipomoke, S., 1986. Economic Analysis of the Environmental Impacts of Development Project. Earthscane Publications Limited, UK and Asian Development Bank, Manila, Philippines, pp-30-33.

Elwood, N.E., Mc.Mahon, R.O., 1983. Forestry Financial Analysis I: An Introduction for Landowner. EC-1148 (Reprint, 1998), Oregon, USA.

FAO., 2005. State of the World's Forests 1997. FAO, Rome.

Friday, J.B., Cabal, C., Yanagida, J., 2000. Financial Analysis for Tree Farming in Hawaii. Resource Management, Cooperative Extension Service, Hawaii.

Gittinger, J.P., 1982. Economic Analysis of Agricultural Projects. Baltimore: Johns Hopkins University Press.

Government of Bangladesh., 1979. Bangladesh National Forest Policy 1979. Ministry of Agriculture. Government of the Peoples’ Republic of Bangladesh Dhaka, Bangladesh, P 15.

Government of Bangladesh., 1993. Forestry Master Plan Technical Project. Government of the Peoples’ Republic of Bangladesh, Dhaka. P. 73.

Government of Bangladesh., 1995. Development Perspectives of the Forestry Sector Master Plan. Ministry of Environment and Forestry, Government of the Peoples’ Republic of Bangladesh, Dhaka, pp. 18-59.

Government of Bangladesh., 2001. Banglapedia: National Encyclopedia of Bangladesh (http:/banglapedia.search.com.bd/HT/D_0101.htm).

Government of Bangladesh., 2002. Statistical Pocketbook Bangladesh 2001. Bangladesh. Bureau of Statistics, Ministry of Planning, Dhaka, Bangladesh. pp. 106.

Ismail, M., Miah, M.M., 1973. Studies on some deciduous Sal forests of Bangladesh. In: Ismail, M. (Ed.), Ecology of Bangladesh Vegetation 2. Botanical Survey of Bangladesh, Department of Botany, University of Dhaka, Bangladesh, pp. 165-187. 
Ismail, M., 1968. Some quantitative and sociological analysis of vegetation in Dacca-Mymensingh forests. Dhaka University Studies XVI (B), 75-82.

Khan, N.A., 1998. A Political Economy of Forest Resource Use: Case Studies of Social Forestry in Bangladesh. Ashgate Publishing Company, England.

Khan, N.A., Choudhury, J.K., Huda, K.S., 2004. An overview of Social Forestry in Bangladesh. Forestry Sector Project, Government of Bangladesh, Dhaka, pp. 14-27.

Klemperer, W.D., 1996. Forest economics and Finance. McGraw-Hill Inc., New York. p. 537.

Mishan, E.J., 1982. Cost-Benefit Analysis ( $3^{\text {rd }}$ edn.). London: Allen and Unwin, London, UK.

Muhammed, N., Koike, M., 2005. Can Social Forestry Effectively Contribute to Poverty Alleviation in Rural Bangladesh? A Case Study. In: K. Naito (Ed.), The Role of Forests for Coming Generations- Philosophy and Technology for Forest Resource Management, Japan Society of Forest Planning Press, Tokyo, pp. 107-118.

Muhammed, N., Hossain, M.K., Miah, M.D., 2000. Growth performance of some plantation tree species in Madhupu sal forest areas of Bangladesh. The Chittagong University Journal of Science, Bangladesh 24(1), 99-104.

Muhammed, N., Koike, M., Bitter, A.W., 2004. Investment analysis of teak (Tectona grandis)- A case study on Sylhet Forests of Bangladesh. Journal of Forest planning, Japan 10, 77-86.

Muhammed, N., Koike, M., Sajjaduzzaman, M., Sophanarith, K., 2005a. Reckoning social forestry in Bangladesh: policy and plan versus implementation. Forestry: An International Journal of Forest Research, Oxford University Press, The UK, Vol 78, No. 4, 373-383.

Muhammed, N., Koike, M., Sajjaduzzaman, M., 2005b. A study on land tenure 
Complexities of Sal (Shorea robusta) forests in Bangladesh. International Journal of Agriculture and Biology. Friends Science Publishers, Pakistan, Vol 7, No. 2, 318-320.

Tangail Forest Division., 2004. Tanagail Forest Division at a glance (in Bengali). Tangail, Bangladesh. 